\title{
Nosocomial Infection in an Intensive Care Unit in a Brazilian University Hospital
}

\author{
Adriana Cristina de Oliveira ${ }^{1}$ \\ Christine Tassone Kovner ${ }^{2}$ \\ Rafael Souza da Silva ${ }^{3}$
}

This prospective study aimed to determine the nosocomial infection (NI) incidence in an Intensive Care Unit (ICU), its association with clinical characteristics and occurrence sites. It was carried out among 1.886 patients admitted in an ICU of a University Hospital, from August 2005 to January 2008. Data analysis was done using Fisher's test and Relative Risk (RR). There were 383 NIs (20.3\%). The infections were in the urinary tract $(n=144$; $37.6 \%)$, pneumonia $(n=98 ; 25.6 \%)$, sepsis $(n=58 ; 15.1 \%)$, surgical site $(n=54 ; 14.1 \%)$ and others $(n=29 ; 7.7 \%)$. Hospitalization average was 19.3 days for patients with NI and 20.2 days for those with colonization by resistant microorganisms. The mortality was $39.5 \%$ among patients with NI (RR: 4.4; 3.4-5.6). The NI was associated with patients originated from other units of the institution/emergency unit, more than 4 days of hospitalization, community infection, colonized by resistant microorganisms, using invasive procedures and deaths resulting from NI.

Descriptors: Epidemiologic Surveillance; Cross Infection; Intensive Care Units.

\footnotetext{
${ }^{1}$ RN, Faculty, Escola de Enfermagem, Universidade Federal de Minas Gerais, MG, Brazil. E-mail: adrianacoliveira@gmail.com. 2 RN, Faculty, New York University, College of Nursing, NY, USA. E-mail: nepircs@hotmail.com.

${ }^{3}$ Nursing Undergraduate Student, Escola de Enfermagem, Universidade Federal de Minas Gerais, MG, Brazil. E-mail: rafeudes@ yahoo.com.br.
}

Corresponding Author:

Adriana Cristina de Oliveira

Universidade Federal de Minas Gerais. Escola de Enfermagem

Av. Alfredo Balena $s / n$

Bairro Santa Efigênia

CEP: 30130-100 Belo Horizonte, MG, Brasil

E-mail: adrianacoliveira@gmail.com 


\section{Infecção hospitalar em unidade de tratamento intensivo de um hospital universitário brasileiro}

Este estudo prospectivo objetivou determinar a incidência da infecção hospitalar (IH) em uma unidade de terapia intensiva (UTI), sua associação com características clínicas do paciente e sítios de ocorrência. Inclui-se 1.886 pacientes de UTI de um hospital universitário, entre agosto de 2005 e janeiro de 2008. Utilizou-se, neste estudo, o teste exato de Fisher e Risco Relativo. Foram identificadas 383 (20,3\%) IH: 144 (37,6\%) do trato urinário, $98(25,6 \%)$ pneumonia, $58(15,1 \%)$ sepses, $54(14,1 \%)$ do sítio cirúrgico e 29 (7,7\%) outras. A permanência média foi de 19,3 dias para pacientes com IH e 20,2 dias para colonizados com microrganismos resistentes. Registrou-se 39,5\% óbitos entre pacientes com IH (RR: 4,4;3,4-5,6). A IH esteve associada a pacientes provenientes de outras unidades da instituição/unidade de emergência, permanência superior a 4 dias de internação, infecção comunitária à internação, colonizados por microrganismos resistentes, em uso de procedimentos invasivos e óbitos resultantes de IH.

Descritores: Vigilância Epidemiológica; Infecção Hospitalar; Unidades de Terapia Intensiva.

\section{Infección hospitalaria en unidad de tratamiento intensivo de un hospital universitario brasileño}

Este estudio prospectivo tuvo como objetivo determinar la incidencia de infección hospitalaria (IH) en una Unidad de Terapia Intensiva (UTI), su asociación con características clínicas del paciente y sitios de ocurrencia. Fueron incluidos 1886 pacientes de la UTI de un hospital universitario, entre agosto de 2005 y enero de 2008. Se utilizó el test exacto de Fisher y Riesgo Relativo. Fueron identificadas 383 (20,3\%) IH: $144(37,6 \%)$ del tracto urinario, $98(25,6 \%)$ neumonía, 58 (15,1\%) sepsis, $54(14.1 \%)$ sitio quirúrgico y $29(7,7 \%)$ otras infecciones. La permanencia promedio fue 19,3 días para pacientes con IH y 20,2 días para colonizados con microorganismos resistentes. Se registró 39.5\% óbitos entre pacientes con IH (RR: 4,$4 ; 3,4-5,6$ ). La IH estuvo asociada a pacientes provenientes de otra unidad de la institución/unidad de emergencia, internación mayor que 4 días, con infección comunitaria, colonizados por microorganismos resistentes, uso de procedimientos invasivos y óbitos resultantes de IH.

Descriptores: Vigilancia Epidemiológica; Infección Hospitalaria; Unidades de Terapia Intensiva.

\section{Introduction}

The $21^{\text {st }}$ century reveals a new healthcare scenario as result of scientific and technological progress. New infectious agents are documented and infections resurged with new strength(1), especially in Intensive Care Units (ICU). Nosocomial infections (NI) are more severe in these high technology hospital units which hold acutely ill patients needing intensive life support ${ }^{(1-3)}$.
ICU nosocomial infections are primarily related to the patient's health status, invasive device utilization such as venous central line, long term urinary catheterization and mechanical ventilation, use of imunosupressors, prolonged hospitalization, colonization by resistant microorganisms, antibiotics prescription and the setting itself which propitiate bacterial natural selection ${ }^{(2-5)}$. 
ICU nosocomial infection rate varies from 18 to $54 \%$, five to ten times higher than other hospital units' rates. It is responsible for 5 to $35 \%$ of all NI and for approximately $90 \%$ of all outbreaks of diseases in an $\operatorname{ICU}^{(2-3,6-7)}$. The ICU high mortality rates, commonly ranging from 9 to $38 \%$, can reach $60 \%$ due to nosocomial infection occurrence ${ }^{(5,8)}$.

This study aimed to determine the nosocomial infection incidence in an ICU, its association with clinical characteristics (gender, age, provenance, medical profile, ICU length-of-stay (days), community infection, colonization by resistant microorganisms, invasive devices use, and deaths) and occurrence sites. As secondary objective, the study aimed to identify the more common microorganisms responsible for NI and their resistance status.

Results of the present study contribute to support results of other studies on NI and may serve as comparison with other health establishments' NI rates. The study adds knowledge on ICU infection rate and emphasizes the importance of performing the control of its related outcomes.

\section{Material and methods}

The study design was prospective, descriptive and epidemiological. Data was collected in an adult ICU of a University Hospital. The Unit has 18 beds, among which two are specially equipped for patient isolation. Staff team is composed by 10 medical doctors and four residents, four physical therapists, 12 registered nurses and 71 licensed nurses, a total of 101 healthcare professionals. Almost all (90\%) of all admissions are paid by the Unified National Health System and the remainder are paid by private health insurances or by the own patient.

The sample included all the patients who were admitted in the ICU from August 2005 to January 2008 ( $N=1.889)$. Exclusion criteria was uncompleted medical records $(n=03)$. Definitions from the National Nosocomial Infection Surveillance System (NISS) were used $^{(9-11)}$ as follows:

- Community infections: all notified infections at the patient's ICU admittance, whether the infection have appeared in another hospital, another hospital ward or outside any hospital establishment;

- Surgical patients: patients who underwent any surgical procedure, with incision and suture, including videolaparoscopy, in an Operation Room;

- Colonization by resistant microorganisms: isolation identified by laboratorial culture. The notification of colonization/infection by resistant microorganisms is a routine at the study hospital according to this criteria: patients from the emergency unit, patients transferred from other hospitals with hospitalization greater or equal than 72 hours or patients from the own hospital transferred to the ICU with prior stay greater or equal than seven days ${ }^{(12)}$;

- Nosocomial infection: any notified infection in an ICU, after 48 hours of admission in the Unit, or 48 hours after patient's discharge. Urinary tract infections which appear up to seven days after discharge and are associated with long term catheterization are considered NI as well.

Before data collection, the research was approved by the institutional review board, protocol 267/2003, in compliance with Resolution 196/96 of the National Health Council, which regulates research involving human subjects. Data were collected by a trained nursing undergraduate student, from medical charts and patients' microbial count.

The collected data included gender, age, origin, medical profile, ICU length-of-stay, community infection, colonization during the stay in the ICU by resistant microorganisms, invasive device utilization, nosocomial infection, deaths and NI' occurrence sites.

Data were entered in the Statistical Program for Social Sciences (SPSS, version 13.0) and analyzed using Fisher's Exact Test to verify association of the NI with clinical characteristics and demographic variables, and Relative Risk (RR). Confidence Interval (CI) of 95\% and statistical significance of 0.05 was established.

\section{Results}

\section{Demographic characteristics of the sample}

A total of 1.889 patients were admitted in the ICU during data collection, and 1.886 (99.3\%) were eligible for the study. Table 1 presents demographic and clinical data of the sample.

The overall average for the ICU stay was 5.7 days (median= 3 days). The average for patients who did not acquire NI was 3.7 days (median $=3$ days) and 19.3 days (median= 13 days) for those who had NI. For the non-colonized patients, the average ICU stay was 3.8 days (median $=3$ days) and 20.2 days (median $=14$ days) for those colonized by resistant microorganisms.

The majority $(n=1.407 ; 74.6 \%)$ used invasive device, among which urinary catheter $(68.5 \%)$, venous central line (49.6\%) or mechanical ventilation (49.9\%). The averages of days under the devices were 5.2, 6.6 and 5.3 , respectively. 
Table 1 - Distribution of the sample according to the study variables, (Aug. 2005 - Jan. 2008). Brazil, 2008

\begin{tabular}{|c|c|c|c|c|}
\hline \multirow{2}{*}{ Variables } & \multirow{2}{*}{ Categories } & \multicolumn{3}{|c|}{$\mathrm{ICU}(\mathrm{N}=1.886)$} \\
\hline & & $\mathbf{N}$ & $\%$ & SD \\
\hline \multirow[t]{2}{*}{ Gender } & Male & 999 & 53.0 & - \\
\hline & Female & 887 & 47.0 & - \\
\hline \multirow[t]{3}{*}{ Age } & Mean (years)/Median & 53.3 & 55 & 17.2 \\
\hline & Without infection & 53 & 55 & 17.3 \\
\hline & With infection & 54.7 & 56 & 16.0 \\
\hline \multirow[t]{4}{*}{ Source of admission } & Other hospital units & 917 & 48.6 & - \\
\hline & Community & 797 & 42.3 & - \\
\hline & Emergency department & 158 & 8.4 & - \\
\hline & Other hospitals & 14 & 0.7 & - \\
\hline \multirow[t]{2}{*}{ Patient medical profile } & Medical & 550 & 29.2 & - \\
\hline & Surgical & 1336 & 70.8 & - \\
\hline \multirow[t]{3}{*}{ Number of days in ICU } & Mean (days)/Median & 5.7 & 3 & 9.7 \\
\hline & Without infection & 3.7 & 3 & 3.9 \\
\hline & With infection & 19.3 & 13 & 20.3 \\
\hline \multirow[t]{2}{*}{ Community infection } & No & 1545 & 81.9 & - \\
\hline & Yes & 341 & 18.1 & - \\
\hline \multirow[t]{2}{*}{ Colonized patient during ICU stay } & No & 1660 & 88.0 & - \\
\hline & Yes & 226 & 12.0 & - \\
\hline \multirow[t]{2}{*}{ Invasive device used } & No & 479 & 25.4 & - \\
\hline & Yes & 1407 & 74.6 & - \\
\hline \multirow[t]{2}{*}{ Patients with nosocomial infections } & No & 1640 & 87.0 & - \\
\hline & Yes & 246 & 13.0 & - \\
\hline \multirow[t]{2}{*}{ Outcomes } & Discharges from ICU* & 1691 & 89.7 & - \\
\hline & Deaths & 195 & 10.3 & - \\
\hline
\end{tabular}

* Home discharge, discharge to other wards or hospital transference. SD: Standard deviation

\section{Nosocomial infections incidence and patients outcomes}

The ICU nosocomial infection rate was twenty percent (383 NIs); there were 246 (13.0\%) patients infected and approximately $10 \%(n=195)$ of the patients died.
Urinary infection was the commonest type of NI with $144(37.6 \%)$ cases, followed by pneumonia $(n=98 ; 25.6 \%)$, sepsis $(n=58 ; 15.1 \%)$, surgical site $(n=54 ; 14.1 \%)$ and others $(n=29 ; 7.7 \%)$ (vascular, eye, ear, mouth, nose and throat, skin, reproductive and gastrointestinal systems), as depicted in Figure 1.

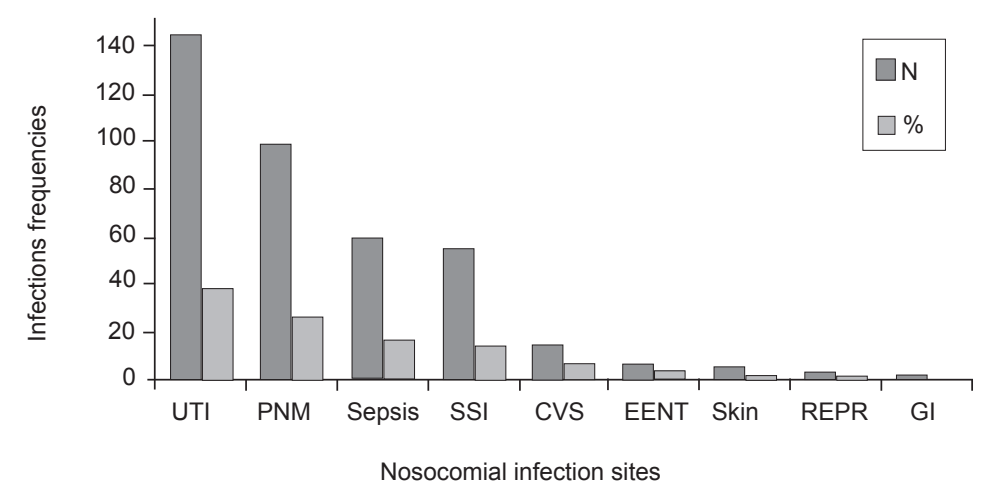

Subtitle: UTI: Urinary Tract Infections; PNM: Pneumonia; SSI: Surgical Site Infections; CVS: Cardiovascular; EENT: Eye, Ear, Nose and Throat, REPR: Reproductive; GI: Gastrointestinal.

Figure 1 - Distribution of the Intensive Care Unit Nosocomial Infections, according to the type of infection, (Aug. 2005 - Jan. 2008). Brazil, 2008 
The distribution of the patients with and without infection is shown in Table 2. Most patients $(n=1.075)$ were hospitalized at the studied hospital prior to admission in the ICU, and among them 177 (16.5\%) developed NI. Those transferred from the hospital emergency unit were more likely to acquire infection (RR: 2.6; CI: 1.8-3.7, p<0.05), than those who came from the community. Also, a relative risk of 1.9 (CI: 1.4-2.4, $\mathrm{p}<0.05$ ) was verified for those who came from another units within the hospital, when compared with those who came from the community.

As reported by other studies in the field, the length-of-stay for more than four days, the episode of community infection, the colonization by resistant microorganisms, and the use of invasive devices were significantly associated with the occurrence of NI, with high relative risks indexes (more than 2.4). Furthermore, among the 195 deaths in the ICU during the study, 77 patients $(39.5 \%)$ had developed NI.

Table 2 - Comparison of the patients with and without nosocomial infection, (Aug. 2005 - Jan. 2008). Brazil, 2008

\begin{tabular}{|c|c|c|c|c|c|}
\hline \multirow{4}{*}{ Variables } & \multirow{4}{*}{ Category } & \multicolumn{4}{|c|}{ Intensive Care Unit } \\
\hline & & \multicolumn{2}{|c|}{ Nosocomial infection } & \multirow{3}{*}{$P^{*}$} & \multirow{3}{*}{$\mathbf{R} \cdot \mathbf{R}^{* *}$} \\
\hline & & \multicolumn{2}{|c|}{$N=246$} & & \\
\hline & & No $(\%)$ & Yes (\%) & & \\
\hline \multirow[t]{2}{*}{ Gender } & Female & $766(86.4)$ & $121(13.6)$ & & 1.0 \\
\hline & Male & $874(87.5)$ & $125(12.5)$ & 0.46 & $0.9[0.7-1.2]$ \\
\hline \multirow[t]{2}{*}{ Age } & $11-55$ & $840(87.9)$ & $116(12.1)$ & & 1.0 \\
\hline & $56-99$ & $800(86.0)$ & $130(14.0)$ & 0.26 & $1.2[0.9-1.5]$ \\
\hline \multirow[t]{4}{*}{ Provenance } & Community & $729(91.5)$ & $68(8.5)$ & & 1.0 \\
\hline & Other hospital units & $774(84.4)$ & $143(15.6)$ & $<0.01$ & $1.9[1.4-2.4]$ \\
\hline & Emergency department & $124(78.5)$ & $34(21.5)$ & $<0.01$ & $2.6[1.8-3.7]$ \\
\hline & Other hospital & $13(92.9)$ & $1(7.1)$ & 0.75 & $0.9[0.1-5.7]$ \\
\hline \multirow[t]{2}{*}{ Medical profile } & Medical & $480(87.3)$ & $70(12.7)$ & & 1.0 \\
\hline & Surgical & $1160(86.8)$ & $176(13.2)$ & 0.85 & $1.0[0.8-1.3]$ \\
\hline \multirow[t]{2}{*}{ ICU length-of-stay (days) } & $1-3$ & $1606(92.4)$ & $132(7.6)$ & & 1.0 \\
\hline & $>4$ & $34(23.0)$ & $114(77.0)$ & $<0.01$ & $10.2[8.5-12.3]$ \\
\hline \multirow[t]{2}{*}{ Community infection } & No & $1383(89.5)$ & $162(10.5)$ & & 1.0 \\
\hline & Yes & $257(75.4)$ & $84(24.6)$ & $<0.01$ & $2.4[1.9-3.0]$ \\
\hline Colonization by resistant & No & $1552(93.5)$ & $108(6.5)$ & & 1.0 \\
\hline microorganisms & Yes & $88(38.9)$ & $138(61.1)$ & $<0.01$ & $9.5[7.7-11.7]$ \\
\hline \multirow[t]{2}{*}{ Invasive devices use } & No & $472(98.5)$ & $7(1.5)$ & & 1.0 \\
\hline & Yes & $1168(83.0)$ & $239(17.0)$ & $<0.01$ & $11.6[5.5-24.4]$ \\
\hline \multirow[t]{2}{*}{ Deaths } & No & $1522(90.0)$ & $169(10.0)$ & & 1.0 \\
\hline & Yes & $118(60.5)$ & $77(39.5)$ & $<0.01$ & $4.4[3.4-5.6]$ \\
\hline
\end{tabular}

*p-value

${ }^{* *}$ Relative Risk

\section{Discussion}

Patients who were derived within and hospitalized prior to ICU admission had a risk of 1.93 (CI: 1.48-2.49) higher for acquiring NI in the ICU when compared to those admitted from the community. Consistent with our findings, results of studies developed in North America, using similar sample, showed double risk for developing ICU nosocomial infection for patients transferred from an emergency room or other hospital unit than those who came from the community, or from another hospital(13-14).

Among the 151 patients who had hospital length of stay greater than four days, 114 (77\%) developed $\mathrm{NI}$, indicating that prolonged hospitalization constitutes a risk factor for infection development $(p<0.01 ; R R$ : 10.2; CI: 8.5-12.3). For a period from four to 11 days after the $17^{\text {th }}$ ICU hospitalization day, the risk for NI development increased. Nosocomial infection rate for patients hospitalized from 17 to 21 days was 1.1, while for those hospitalized from 43 to 134 days the infection rate was 3.1, result similar to Latin-American and European studies, which demonstrated relationship between longer hospitalization and infection $(7,9,15)$.

Out of the 341 patients who came from the community, 84 (24.6\%) developed NI ( $p<0.01$ RR: 2.4 CI: 1.9-3.0). Studies report that patients with any infection diagnosis by 
the ICU admission had higher risk of developing NI in the Unit compared with those who did not have prior infection (RR: 0.25; CI: 0.07-0.86; p <0.05)(16).

Patients colonized by resistant microorganisms evidenced a high NI rate $(61.6 \%)$ and had a relative risk of 9.5 (CI: 7.7-11.7; p <0.05) when compared with those who did not have colonization by the resistant microorganisms. In the sample were isolated 343 cases of colonization (an average of 1.5 per patient), by 13 different resistant microorganisms; the five most common represented more than $90 \%$ of cases (Acinetobacter baumannii, 36.3\%; Pseudomonas aeruginosa, 21.9\%; MRSA, 14.7\%; Klebsiella pneumonia, 11.0\%; and Escherichia coli, 7.8\%). However, this does not mean that the NI was caused by the isolated resistant microorganisms, only that the colonization in many situations was associated with the presence of the same or other microorganisms in the NI.

Indeed, in some cases the resistant microorganisms identified as causing the NI were different. In 146 of 383 cases the NI was caused by 25 different non resistant microorganisms, in 74 cases the diagnosed NI was caused by at least 9 different resistant microorganisms, and in 163 cases of NI it was not clear from the records what was the specific microorganism neither the resistance status.

The more frequent non resistant microorganisms responsible for the NI were Candida albicans (18.5\%), Escherichia coli (15.1\%), Pseudomonas aeruginosa $(8.9 \%)$, Enterobacter cloacae $(8.2 \%)$, and Enterococcus faecalis $(8.2 \%)$. Among the more frequent multi-drug resistant microorganisms causing NI were identified Acinetobacter baumannii (35.1\%), Pseudomonas aeruginosa $(21.6 \%)$, and MRSA, Klebsiella pneumonia and Escherichia coli (10.8\%).

Most of the patients used at least one invasive device. Approximately $70 \%(n=1.292)$ of the patients used long term urinary catheter, $49.9 \%(n=942)$ used mechanical ventilation and $49.6 \%(n=935)$ venous central line, demonstrating high device utilization in the Unit.

Researchers report that urinary tract infection (UTI) associated with long term urinary catheterization accounts for 8 to $35 \%$ of all ICU infections. The most prevalent urinary infection found in the studies were asymptomatic bacteriuria ${ }^{(4,8,14)}$. In the present study, UTI were responsible for $37.6 \%(n=144)$ of all reported ICU infections, among which $76.4 \% \quad(n=110)$ were asymptomatic and $33.6 \%(n=34)$ were symptomatic.

NNIS (National Nosocomial Infections Surveillance System) data indicates that pneumonias account for $31 \%$ of all ICU infections. Some authors believe that nosocomial pneumonia is the second commonest NI and the most common NI cause of death. This is consistent with results of the present study, where pneumonia was present in $25.6 \%(n=98)$ of NI, however less common than $\mathrm{UTI}^{(8,17-18)}$.

Among the 195 deaths $(10.3 \%), 39.5 \% \quad(n=77)$ were patients who developed NI, a datum consistent with findings of others researches that found a positive relation between higher mortality rates and NI diagnosis ${ }^{(5,7-8)}$.

Based on our findings, we suggest periodical discussions among the healthcare team about NI rates, resistant microorganism profile at the institution, and mortality rate associated with them, in seminars, clinical meetings, or training sessions. Moreover, to encourage team participation and raise awareness about the importance of NI prevention campaigns. Those activities can contribute to healthcare management, allow an overview of tendencies and fluctuations of infections, and provide information for the creation and review of protocols.

\section{Conclusion}

Nosocomial infection rate was $20.3 \%$ in 246 patients. The ICU NI rate in the present study was consistent with the literature. The commonest infection was in the Urinary tract, followed by pneumonia, sepsis, surgical site infection and others (vascular, eye, ear, mouth, nose and throat, skin, reproductive and gastrointestinal systems).

The average hospitalization was 19.3 days for patients with NI and 20.2 days for those with colonization by resistant microorganism. The mortality rate was $39.5 \%$ among patients with NI (RR: $4.4 ; 3.4-5.6)$. The NI was associated with patients originated from other units of the institution/emergency unit, more than 4 days of hospitalization, community infection, colonized by resistant microorganisms, using invasive devices and deaths resulting from NI.

The most common non resistant microorganisms responsible for the NI were Candida albicans, Escherichia coli and Pseudomonas aeruginosa. And those identified as most frequent multi-drug resistant microorganisms causing NI were Acinetobacter baumannii and Pseudomonas aeruginosa.

The results of this study contribute to support other studies on NI, and reaffirm the importance of an effective program for infection control with the involvement of healthcare workers. The study adds knowledge on ICU infection rate and emphasizes the importance of performing the control of its related outcomes such as patient risk, mortality and occurrence of resistant microorganisms. 


\section{References}

1. Lima ME, Andrade D, Haas VJ. Avaliação prospectiva da ocorrência de infecção em pacientes críticos de Unidade de Terapia Intensiva. Rev Bras Ter Intensiva 2007; 19(3):342-7.

2. Allen S. Prevention and control of infection in the ICU. Curr Anaesth Crit Care. 2005; 16(4):191-9.

3. Gusmão MEN, Dourado I, Fiaccone RI, Salvador C. Nosocomial pneumonia in the intensive care unit of a brazilian university hospital: na analysis of the time span from admission to disease onset. Am J Infect Control 2004; 32(4):209-14.

4. Wagenlehner FME, Loibl E, Vogel H, Naber KG. Incidence of nosocomial urinary tract infections on a surgical intensive care unit implications for management. Int J Antimicrob Agents 2006; 28(1):86-90.

5. Colpan A, Akinci E, Erbay A, Balaban N, Bodur H. Evaluation of risk factors for mortality in intensive care units: a prospective study from a referral hospital in Turkey. Am J Infect Control 2005; 33(1):42-7.

6. Espósito S, Leone S. Antimicrobial treatment for Intensive Care Unit (ICU) infections including the role of the infectious disease specialist. Int J Antimicrob Agents 2007; 29(5):494-500.

7. Rosenthal VD, Guzman S, Orellano PW. Nosocomial infections in medical-surgical intensive care units in Argentina: attributable motality and lenght of stay. Am J Infect Control 2003; 31(5):291-5.

8. Vincent JL. Nosocomial infections in adult intensive care units. Lancet 2003; 361(9374): 2068-77.

9. Martins MA. Conceitos gerais e terminologia básica em epidemiologia hospitalar e controle de infecção. In: Martins MA. Manual de infecção hospitalar: epidemiologia, prevenção e controle. Belo Horizonte: Medsi; 2001. p. 16-26.

10. Rezende EM, Santos AAM, França E. Vigilância epidemiológica das infecções hospitalares. In: Oliveira AC. Infecções hospitalares: epidemiologia, prevenção e controle. Rio de Janeiro: Guanabara Koogan; 2005. p. 15-33.

11. Azevedo FM, Paiva LFR. O laboratório no controle de infecção hospitalar. In: Martins MA. Manual de infecção hospitalar: epidemiologia, prevenção e controle. Belo Horizonte: Medsi; 2001. p .435-48.

12. Oliveira AC, Horta B, Martinho GH, Dantas LV, Ribeiro MM. Nosocomial infections and bacterial resistance in patients from a Teaching Hospital Intensive Care Unit. Online Braz J Nurs, 2007; 6:1-132.

13. Urli T, Perone G, Acquarolo A, Zappa S, Antonini B, Candiani A. Surveillance of infections acquired in intensive care: usefulness in clinical practice. J Hosp Infect 2002; 52(2):130-5.

14. McCusker ME, Périssé ARS, Roghmann MC. Severity-ofillness markers as predictors of nosocomial infection in adult intensive care unit. Am J Infect Control 2002; 30(3):139-44.

15. Orsi GB, Scorzolini L, Franchi C, Mondillo V, Rosa F. Denditti $M$. Hospital-acquired infection surveillance in a neurosurgical intensive care unit. J Hosp Infect 2006; 64(1):23-9.

16. Beyersmann J, Gastmeier P, Grundmann H, Bärwolff $S$, Geffer C, Behnke M, et al. Transmission-associated nosocomial infections: prolongation of intensive care unit stay and risk factor for analysis using multistate models. Am J Infect Control 2008; 36(2):98-103.

17. Zeitoun SS, Barros ALBL, Diccinia S. Incidência de pneumonia associada à ventilação mecânica em pacientes submetidos à aspiração endotraqueal pelos sistemas aberto e fechado: estudo prospectivo - dados preliminares. Rev Latino-am Enfermagem 2001; 9(1):46-52.

18. Mesiano ERAB, Merchán-Hamann. Bloodstream infections among patients using central venous catheters in intensive care units. Rev Latino-am Enfermagem 2007; 15(3):453-9. 